\title{
PENGARUH BIMBINGAN KELOMPOK UNTUK MENINGKATKAN KREATIVITAS SISWA DALAM MEMECAHKAN MASALAH
}

\author{
Sri Hermawati \\ SMP NEGERI 3 MAKARTI JAYA \\ Email: srihermawati245@gmail.com
}

\begin{abstract}
ABSTRAK
Penelitian ini dilakukan dengan tujuan untuk mengetahui pengaruh dari bimbingan kelompok untuk meningkatkan kreativitas siswa dalam memecahkan masalah di Sekolah Menengah Pertama Negeri 3 Makarti Jaya tahun ajaran 2019/2020. Metode yang digunakan dalam penelitian ini adalah metode quasi exsperiment dengan One Grup Pretest dan Postest Design. Sampel dalam penelitian ini adalah siswa kelas VIII dengan jumlah total 10 orang. Data mengenai kreativitas dalam memecahkan masalah diperoleh dari angket kreativitas siswa. Analisis data menggunakan uji-t, dengan terlebih dahulu menghitung rata-rata dari Pre-Test dan Post-Tes. Hasil penelitian menunjukkan bahwa Nilai rata-rata postest lebih besar dibandingkan nilai rata-rata pretest yaitu $60>44$, Nilai $t_{\text {hitung }}>t_{\text {tabel }}$ yaitu 8,138>1,833 dengan taraf signifikan 5\%, ini berarti terdapat perbedaan kreativitas dalam memecahkan masalah antara pretest dan postest secara signifikan. Hal ini menunjukkan bahwa Bahwa adanya pengaruh bimbingan kelompok dalam meningkatkan kreativitas siswa dalam belajar di Sekolah Menengah Pertama Negeri 3 Makarti Jaya.
\end{abstract}

Kata Kunci: Bimbingan Kelompok, Kreativitas Memecahkan Masalah.

\section{THE INFLUENCE OF THE GROUP GUIDANCE TO INCREASE STUDENT'S CREATIVITY IN SOLVING PROBLEMS}

\begin{abstract}
ABSTRACK
This research was conducted to study the motivation of groups to increase student creativity in solving problems in Public Junior High School 3 Makarti Jaya in 2019/2020 school year. The method used in this research is a quasi exsperiment with One Grup Pretest dan Postest Design. The samle in thia study were students of class VIII with a total of 10 people. Data about creativitu in solving problems obtained from student creativity questionnaries. Data analisys using t-test, by fist calculating the average of the Pre-Test and Post-Test. The result showed that the average value of the postest was greater than the average value of the pretest which was $60>44$, the value of tcount > ttaable was 8,138>1,833 with a significant level of 5\%, this was related to the benefits of increasing knowledge about pretest and postest problems with significant. This show what is meant by participation in increasing student creativity in learning at Public Junior High School 3 Makarti Jaya.
\end{abstract}

Keyword: Group Guidance, Creativity in Solving Problems. 


\section{PENDAHULUAN}

Kreativitas merupakan bakat yang potensial yang dimiliki setiap orang yang dapat diidentifikasikan dan dipupuk melalui pendidikan yang tepat, salah satu masalah yang kritis ialah bagaimana dapat meningkatkan kreativitas siswa dalam memecahkan masalah dan bagaimana dapat mengembangkannya melalui pengalaman pendidikan. Kreativitas merupakan kunci sukses dan keberhasilan kehidupan. Bila bakat kreatif anak tidak dipupuk maka bakat tersebut tidak akan berkembang, bahkan menjadi bakat terpendam yang tidak dapat diwujudkan.

Menurut Munandar (2009:12).Kreativitas adalah hasil dari interaksi antara individu dan lingkungannya, seseorang mempengaruhi dan dipengaruhi oleh lingkungan dimana ia berada, dengan demikian baik perubahan di dalam individu maupun di dalam lingkungan dapat menunjang atau menghambat upaya kreatif. Jadi dapat disimpulkan bahwa pada dasarnya kreativitas adalah proses interaksi antara individu dan lingkungan dapat mempengaruhi dan dipengaruhi bakat, potensi dan perbahan didalam individu.

Demikian pentingnya kreativitas,sehingga perlu dipupuk dalam diri anak sejak dini. Rahmawati dan Kurniati: 2005 mengemukakan bahwa kreativitas perlu dikembangkan sejak dini, karena dengan berkreasi orang dapat mewujudkan (mengaktualisasikan) dirinya, dan perwujudan/aktualisasi diri merupakan kebutuhan pokok tingkat tertinggi dalam hidup manusia.Pentingnya pengembangan kreativitas bagi siswa sekolah juga telah tertulis dalam tujuan Pendidikan Nasional Indonesia dan Peraturan Menteri Pendidikan Nasional nomor 22 tahun 2006 tentang standar isi. Dalam Undang-undang Nomor 20 Tahun 2003 pasal 1 tentang Sistem Pendidikan Nasional (Depdiknas, 2003) disebutkan bahwa salah satu tujuan pendidikan nasional adalah mendidik peserta didik menjadi manusia yang kreatif.

Tujuan dalam pendidikan pada umumnya untuk menyediakan tempat yang memungkinkan bagi siswa untuk mengembangkan kreativitas secara optimal sehingga ia dapat mewujudkan dirinya dan berfungsi sepenuhnya dan sesuai dengan kebutuhan pribadinya dan kebutuhan masyarakat. Setiap inividu mempunyai kreatif yang berbeda-beda dan oleh karena itu membutuhkan pendidikan yang berbeda-beda 
pula pada pengembangan kreativitas yang dimiliki oleh siswa. Jadi, tujuan pendidikan di atas adalah untuk membentuk kualitas manusia yang memiliki kreativitas.

Berdasarkan observasi di Sekolah Menengah Pertama Negeri 3 Makarti Jaya, bedasarkan survey dan juga informasi dari guru bimbingan dan konseling peneliti menemukan permasalahan bahwasannya Siswa masih rendah kreativitasnya disekolah seperti mudah menyerah, tidak mempunyai imajinasi yang luas, tidak mudah tangap. Sehubungan dengan proses pendidikan di sekolah, ini merupakan tugas guru termasuk guru Bimbingan dan Konseling melalui layanan bimbingan dan konseling karena sebagaimana disebutkan bahwa salah satu tujuan bimbingan dan konseling adalah membantu mengembangkan potensi siswa secara optimal. Salah satu teknik yang dapat digunakan adalah bimbingan kelompok.

\section{LANDASAN TEORI}

Menurut Prayitno dan Amti (2004:309) "Bimbingan kelompok adalah layanan bimbingan yang diberikan dalam suasana kelompok”. Gazda (1978) "mengemukakan bahwa bimbingan kelompok disekolah merupakan kegiatan informasi kepada sekelompok siswa untuk membantu mereka menyusun rencana dan keputusan yang tepat" adi dapat di simpulkan bahwa pada dasarnya bimbingan kelompok ialah proses pemberian bantuan yang dilakukan perkelompok untuk mengembangkan potensi yang ada pada individu.

Tujuan layanan bimbingan kelompok secara umum membantu individu yang mengalami masalah dengan prosedur kelompok, serta mengembangkan pribadi masing-masing anggota kelompok melalui berbagai suasana yang muncul dalam kegiatan. Dengan interaksi sosial yang intensif dan dinamis selama berlangsungnya layanan, diharapkan tujuan-tujuan layanan dapat tercapai secara lebih optimal, termasuk didalam peningkatan kreativitas (Murnita: 2016). Keunggulan layanan bimbingan kelompok adalah didalam layanan bimbingan kelompok dapat terjadi saling tukar pengalaman diantara para anggotanya yang dapat berpengaruh terhadap perubahan tingkah laku. 
Hasil implementasi pada penelitian wahyuni fitri pada yahun 2013 menunjukkan bahwa layanan bimbingan kelompok terbukti efektif mengembangkan kreativitas siswa. Tingkat kreativitas siswa mengalami kenaikan sebesar 8,2\% dari sebelumnya $66,1 \%$ meningkat menjadi $74,3 \%$. Peningkatan tersebut terjadi pada semua aspek kreativitas. Hasil uji statistik wicoxon menunjukkan nilai probabilitas dibawah $0,005(0,0025<0,05)$, artinya bahwa bimbingan kelompok efektif untuk mengembangkan kreativitas siswa.

Berdasarkan penjelasan di atas maka penulis akan melaksanakan penelitian dengan judul "Pengaruh Bimbingan Kelompok Untuk Meningkatkan Kreativitas Siswa Dalam Memecahkan Masalah di Sekolah Menengah Pertama Negeri 3 Makarti Jaya".

\section{METODOLOGI}

Metode penelitian yang digunakan ialah pendekatan kuantitatif dengan metode Eksperimen yaitu pre experimental design dengan One Grup Pretest dan Postest Design (Sugiyono, 72: 2010) . Karena tidak ada perbandingan dengan kelompok kontrol, sehingga satu kelompok tes diberikan satu perlakuan yang sama sebelum dan sesudah mendapatkan perlakuan tertentu (Emzir, 2015: 96).

Populasi penelitian ini yaitu seluruh siswa kelas VIII di Sekolah Menengah Pertama Negeri 3 Makarti Jaya tahun ajaran 2019/2020, yang berjumlah 52 siswa yang terdiri dari kelas VIII A dan VIII B. Sampel dalam penelitian ini diambil menggunakan teknik purposive sample yang dilakukan dengan cara mengambil sampel saran dari guru bimbingan dan konseling. Sampel dalam penelitian ini adalah siswa kelas VIII dengan jumlah total 10 orang.

Instrumen yang digunakan dalam penelitian ini adalah angket dengan skala likert. Sebelum angket disebarkan kepada sampel, angket harus di uji coba kepada siswa sebanyak 20 siswa untuk mengukur tingkat validitas dan reabilitasnya. Angket yang diberikan pada siswa yang tidak dipilih sebagai sampel tetapi masuk dalam perhitungan populasi penelitian. Teknik analisis data yang digunakan adalah rumus uji-t, dengan terlebih dahulu menghitung rata-rata dari Pre-Test dan Post-Tes. 


\section{HASIL PENELITIAN}

\section{Deskripsi Data}

Sebelum dilakukan layanan bimbingan kelompok yang diberikan kepada sampel yang berjumlah 10 siswa, terlebih dahulu diberikan Pre-Test untuk dapat memperoleh gambaran awal dan untuk dapat mengetahui tingkat kreatifitas peserta didik sebelum diberikan layanan bimbingan kelompok. Angket Pre-Test berupa angket Skala Likert dengan 5 kemungkinan alternative jawaban yaitu Sangat Setuju (SS) diberi skor 5, Setuju (S) diberi skor 4, Ragu-Ragu (RR) diberi skor 3, Tidak Setuju (TS) diberi skor 2, Sangat Tidak Setuju (STS) diberi skor 1 (Sugiyono, 2010:135).

Berikut ini deskripsi data kreativitas memecahkan masalah siswa berdasarkan pada hasil skor pre-test.

\section{Tabel 1. Nilai Pre-Test}

\begin{tabular}{ccc}
\hline No & Responden & Hasil Pretest \\
\hline $\mathbf{1}$ & Responden 1 & 36 \\
$\mathbf{2}$ & Responden 2 & 47 \\
$\mathbf{3}$ & Responden 3 & 42 \\
$\mathbf{4}$ & Responden 4 & 37 \\
$\mathbf{5}$ & Responden 5 & 41 \\
$\mathbf{6}$ & Responden 6 & 51 \\
$\mathbf{7}$ & Responden 7 & 46 \\
$\mathbf{8}$ & Responden 8 & 44 \\
$\mathbf{9}$ & Responden 9 & 48 \\
$\mathbf{1 0}$ & Responden 10 & 48 \\
& Jumlah & $\mathbf{4 4 0}$ \\
& Rata-Rata & $\mathbf{4 4}$ \\
\hline
\end{tabular}

Analisis berdasarkan tabel pretest yang di ketahui jumlah nilai pretest $=440$ dengan rata-rata $=44$. Nilai maksimal pretest adalah 51 dan nilai minimum pretest adalah 36, maka range nya adalah 51-36 $=15$. Jika interval kelasnya ditetapkan 5 , maka dengan menggunakan range jumlah kelasnya adalah $15: 5=3$. Berdasarkan tabel 1 di ketahui jumlah nilai pretest $=440$ dengan rata-rata $=44$. Kesimpulan 
adalah kreativitas siswa dalam memecahkan masalah sebelum dilaksanakan layanan bimbingan kelompok dengan teknik diskusi kelompok berkategori cukup.

Setelah diberikan bimbingan kelompok, angket untuk menilai Kreativitas siswa siswa yang diberikan saat mengukur pre-test diberikan lagi kepada siswa guna mengukur kreativitas siswa. Angket post-test yang digunakan sama seperti angket saat diberikannya pre-test. Berdasarkan angket yang telah diberikan diperolehlah skor total post-test sebagai berikut:

\section{Tabel 2 Nilai postest}

No
1
2
3
4
5
6
7
8
9
10
Jumlah
Rata-Rata

\section{Responden}

Responden 1

Responden 2

Responden 3

Responden 4

Responden 5

Responden 6

Responden 7

Responden 8

Responden 9

Responden 10
Hasil Postest

63

56

60

58

58

62

66

63

57

57

600

60

Berdasarkan tabel di atas di ketahui jumlah nilai postest $=600$ dengan ratarata $=60$. Pedoman analisis berdasarkan tabel postest yang di ketahui jumlah nilai postest $=600$ dengan rata-rata $=60$. Nilai maksimal postest adalah 66 dan nilai minimum postest adalah 56, maka range nya adalah $66-56=10$. Jika interval kelasnya ditetapkan 5, maka dengan menggunakan range jumlah kelasnya adalah 10 : $5=2$. Berdasarkan tabel 2 di ketahui bahwa rata-rata postest adalah 60, dengan kategori cukup. Kesimpulan adalah kreativitas siswa dalam memecahkan masalah setelah dilaksanakan layanan bimbingan kelompok dengan menggunakan teknik diskusi kelompok berkategori cukup. 


\section{Uji Hipotesis}

Dalam hal ini untuk mengetahui ada tidaknya pengaruh bimbingan kelompok untuk meningkatkan kreativitas dalam memecahkan masalah siswa maka data yang hendak di uji adalah data hasil pretest (sebelum diberi layanan) dan postest (Setelah diberi layanan). Dengan kriteria atau kaidah uji hipotesis untuk menentukan kesimpulan hasil analisis data dengan membandingkan $\mathrm{t}_{\text {hitung }}$ dan $\mathrm{t}_{\text {tabel. }}$. Penghitungan nilai t dapat dilihat pada tabel berikut ini :

\section{Tabel 3 Hasil Penghitungan Uji-t}

$\begin{array}{llccccc}\text { No } & \text { Responden } & \text { Pretest } & \text { Postest } & \begin{array}{c}\text { Gain (d) } \\ \text { (Postest-Pretest) }\end{array} & \mathbf{X}_{\mathbf{d}}\left(\mathbf{d}-\mathbf{M}_{\mathbf{d}}\right) & \mathbf{X}_{\mathbf{d}}{ }^{2} \\ \mathbf{1} & \text { Responden 1 } & 36 & 63 & 27 & 11 & 121 \\ \mathbf{2} & \text { Responden 2 } & 47 & 56 & 9 & -7 & 49 \\ \mathbf{3} & \text { Responden 3 } & 42 & 60 & 18 & 2 & 4 \\ \mathbf{4} & \text { Responden 4 } & 37 & 58 & 21 & 5 & 25 \\ \mathbf{5} & \text { Responden 5 } & 41 & 58 & 17 & 1 & 1 \\ \mathbf{6} & \text { Responden 6 } & 51 & 62 & 11 & -5 & 25 \\ \mathbf{7} & \text { Responden 7 } & 46 & 66 & 20 & 4 & 16 \\ \mathbf{8} & \text { Responden 8 } & 44 & 63 & 19 & 3 & 9 \\ \mathbf{9} & \text { Responden 9 } & 48 & 57 & 9 & -7 & 49 \\ \mathbf{1 0} & \text { Responden 10 } & 48 & 57 & 9 & -7 & 49 \\ \text { Jumlah } & \mathbf{4 4 0} & \mathbf{6 0 0} & \mathbf{1 6 0} & & \mathbf{3 4 8} \\ \text { Mean (rata-rata) } & \mathbf{4 4} & \mathbf{6 0} & \mathbf{1 6} & & \end{array}$

$$
M d=\frac{\sum d}{n}=\frac{160}{10}=16
$$

Selanjutnya barulah menggunakan rumus uji-t untuk menguji signifikan

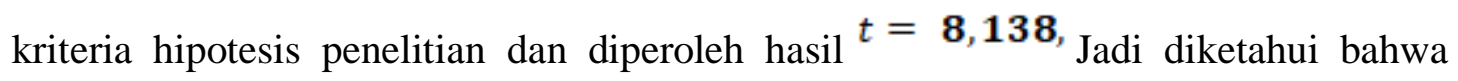

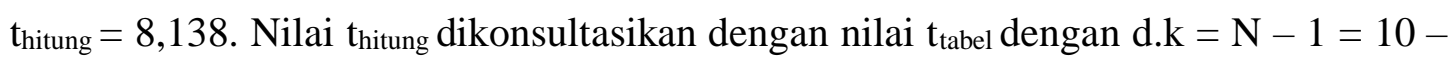
$1=9$. Dengan $t_{0,05}$ maka $t_{\text {tabel }}=1,833$. Jadi hasil dari penghitungan data pretest dan postest diketahui bahwa thitung $>t_{\text {tabel }}$ yaitu 8,138 $>1,833$ dengan taraf signifikan 5\%. Ini berarti bahwa ada perbedan hasil pretest dan postes bimbingan kelompok untuk meningkatkan kreativitas dalam memecahkan masalah siswa di SMP Negeri 3 Makarti Jaya. Jadi dapat disimpulkan bahwa terdapat pengaruh bimbingan kelompok 
untuk meningkatkan kreativitas dalam memecahkan masalah siswa di SMP Negeri 3 Makarti Jaya.

\section{PEMBAHASAN}

Tujuan dari penelitian ini adalah untuk dapat mengetahui seberapa besar pengaruh bimbingan kelompok untuk meningkatkan kreativitas dalam memecahkan masalah siswa di SMP Negeri 3 Makarti Jaya. Pengaruh tersebut diuji dengan pretest (sebelum diberi layanan bimbingan kelompok) dan postest (setelah diberi layanan bimbingan kelompok).

Menurut Narti (2014:17) Bimbingan Kelompok merupakan "suatu cara memberikan bantuan atau bimbingan kepada individu atau siswa melalui kegiatan kelompok". Dalam layanan bimbingan kelompok, aktivitas dan dinamika kelompok harus diwujudkan untuk membahas berbagai hal yang berguna bagi pengembangan atau pemecahan masalah individu atau siswa yang menjadi peserta layanan. Dalam layanan bimbingan kelompok dibahas topik-topik umum yang menjadi kepedulian bersama anggota kelompok.

Bimbingan kelompok yang dilaksanakan dengan cara observasi kepada peserta didik ketika akan dilaksanakan postest, berjalan dengan lancar dan berpengaruh terhadap peningkatan kreativitas siswa dalam memecahkan masalah. Dari hasil penelitian yang telah dilaksanakan menunjukkan bahwa dengan dilakukannya bimbingan kelompok terlebih dahulu maka kreativitas siswa dalam memecahkan masalah siswa akan dikatakan berhasil, karena menunjukan peningkatan pada hasil penelitian. Berdasarakan uji hipotesis diperoleh nilai mean pretest $=44$ dengan kategori cukup, ini berarti kreativitas dalam memecahkan masalah siswa di SMP Negeri 3 Makarti Jaya sebelum diberi layanan bimbingan kelompok dengan teknik diskusi dinilai cukup. Sedangkan pada nilai mean postest diperoleh hasil 60 dengan kategori cukup, ini berarti kreativitas dalam memecahkan masalah siswa di SMP Negeri 3 Makarti Jaya setelah diberi layanan bimbingan kelompok dengan teknik diskusi dinilai cukup. 
Dengan demikian Nilai rata-rata postest lebih besar dibandingkan nilai ratarata pretest yaitu $60>44$. Hal ini berarti setelah dilakukan treatmen bimbingan kelompok dengan teknik diskusi kreativitas dalam memecahkan masalah siswa SMP Negeri 3 Makarti Jaya dengan peningkatan nilai sebesar $60-44=26$. Nilai thitung $>$ $\mathrm{t}_{\text {tabel }}$ yaitu $8,138>1,833$ dengan taraf signifikan $5 \%$, ini berarti terdapat perbedaan kreativitas dalam memecahkan masalah antara pretest dan postest secara signifikan, perbedaan ini dipengaruhi oleh treatmen layanan bimbingan kelompok.

Sukardi (2010:221) menyatakan bahwa tujuan layanan melalui diskusi kelompok adalah sebagai berikut; (1) memperoleh informasi yang berharga dari teman diskusi dan pembimbing diskusi; (2) membangkitkan motivasi dan semangat siswa untuk untuk melakukan suatu tugas; (3) mengembangkan kemampuan berpikir kritis, mampu melakukan analisis dan sintesis atas data atau informasi yang diterima; (4) mengembangkan keterampilan dan keberanian siswa untuk mengemukakan pendapat secara jelas dan terarah; (5)membiasakan kerja sama di antara siswa. Maka dapat disimpulkan bahwa semakin baik layanan bimbingan kelompok dilakukan maka akan semakin meningkatkan hasil bagi siswa dalam kreativitas pemecahan masalah siswa.

\section{KESIMPULAN}

Berdasarkan penelitian dan hasil pembahasan, dapat dikemukakan kesimpulan sebagai berikut.

1. Kreativitas dalam memecahkan masalah siswa di SMP Negeri 3 Makarti Jaya sebelum dilakukan bimbingan kelompok berketegori cukup, karena mean pretest $=44$, kategori cukup.

2. Kreativitas dalam memecahkan masalah siswa di SMP Negeri 3 Makarti Jaya setelah dilakukan bimbingan kelompok berketegori cukup, karena mean pretest $=$ 60, kategori cukup.

3. Ada pengaruh bimbingan kelompok untuk meningkatkan kreativitas dalam memecahkan masalah siswa di SMP Negeri 3 Makarti Jaya, karena $t_{\text {hitung }}>t_{\text {tabel }}$ yaitu $8,138>1,833$. 


\section{DAFTAR PUSTAKA}

Depdiknas. 2003. Undang-undang Nomor 20 Tahun 2003 pasal 1 tentang Sistem Pendidikan Nasional. Jakarta: Depdiknas.

Emzir. 2015. Metodologi penelitian pendidikan. Jakarta: Raja Grafindo Persada.

Munandar, Utami. 2009. Pengembangan Kreativitas Anak Berbakat. Jakarta: Rineka Cipta.

Murnita Arni. 2016. Upaya Meningkatkan Prilaku Pro-Sosial Melalui Layanan Bimbingan Kelompok dengan Metode Sosiodrama, Jurnal Penelitian Tindakan Bimbingan Konseling Vol. 2 No. 1,. https://docplayer.info/45788321-Layanan-bimbingan-kelompok-melaluipermainan-untuk-meningkatkan-perilaku-sosial-peserta-didik.html

Narti, Sri. 2014. Modul Bimbingan Konseling Berbasis Agama islam Untuk Meningkatkan Konsep Diri S, Yogyakarta: Pustaka Pelajar.

Prayitno dan Amti. 2004. Dasar-Dasar Bimbingan dan Konseling. Jakarta: Rineka Cipta.

Rahmawati, Y dan Kurniati, E. 2005. Strategi Pengembangan Kreatifitas Pada AnakAnakl usia Taman Knak-Kanak. Jakarta: Depdikbud.

Sugiyono. 2010. Metode Penelitian Kuantitatif dan Kualitatif, Bandung: Alfabeta.

Sukardi, Dewa Ketut. 2010. Pengantar Pelaksanaan Program Bimbingan dan Konseling. Jakarta: Rineka Cipta.

Wahyuni Fitri, 2013. Pengembangan Model Bimbingan Kelompok dengan Teknik Mind Mapping untuk Mengembangkan Karakteristik, Jurnal Bimbingan Konseling. 